\title{
Antecedents of Perceived Playfulness: An Exploratory Study on User Acceptance of General Information-searching Websites
}

\author{
Janine Chung \\ The University of Auckland, New Zealand \\ Felix B. Tan ${ }^{1}$ \\ Auckland University Of Technology, New Zealand
}

Received 24 March 2003; received in revised form 3 July 2003; accepted 29 Aug 2003

\begin{abstract}
Understanding user acceptance of the Internet, in particular user acceptance of general information-searching sites, is important in assessing its effectiveness. Such sites provide users with various information options while navigating the Internet. A well-designed general information-searching site helps ensure a positive user experience and therefore repeat usage. This study extended existing research into user acceptance of the Internet. It explored the antecedents of Playfulness. Results indicated that website characteristics play a dominant role in influencing a user's experience of Playfulness and that cognitive aspects and motivations for searching are also important. Implications are discussed.
\end{abstract}

Keywords: Technology Acceptance Model, User Acceptance, [Antecedents of] Perceived Playfulness, General information-searching Website, User experience

\footnotetext{
${ }^{1}$ Corresponding author: Felix B Tan, School of Computer and Information Sciences, Auckland University of Technology, Private Bag 92006, Auckland, New Zealand, Ph 649 9179487, Fax 649 9179944, Email felix.tan@aut.ac.nz.
} 


\section{Introduction}

There is a growing stream of research into website effectiveness and success [3,4,23,31].

One aspect of this research stream deals with user acceptance of IT, which is an important factor in establishing its success [12]. Usage of one such technology - the Internet - is growing at an astonishing rate, as there is much potential for users to visit and interact with websites [19]. It is therefore important to conduct research into user acceptance of them. As the Internet increases in popularity, website designers must make sure that their particular site encourages user acceptance.

Due to the unrestrained nature of the Internet and its size, most users need to navigate through various options via an general information-searching site in order to locate the right information [15]. Research into ways in which users might be more accepting of general information-searching sites would therefore be helpful for website designers. User acceptance would also encourage better access to other information on the Internet.

Much of the research into user acceptance of technology make reference to Davis, who first proposed a Technology Acceptance Model (TAM) applied to predict user acceptance of technology [13]. Since then, researchers have criticised its extrinsic focus (e.g.[25]). Malone [24] stated that intrinsic motivation factors might also contribute to user acceptance of technologies. Moon and Kim used an intrinsic factor - Perceived Playfulness. 
They found that Perceived Playfulness was positively related to Attitude Toward Using and Perceived Ease of Use.

This study continues the cumulative research tradition evident in this stream of study. It extends Moon and Kim's work by exploring the antecedents of Perceived Playfulness in the context of general information-searching websites. While antecedents of Perceived Ease of Use and Perceived Usefulness have been included in several other studies (e.g., $[29,30])$, no research has been found which has investigated antecedents of playfulness.

\section{Literature Review}

\subsection{Technology Acceptance Model (TAM)}

Many researchers have used the TAM to predict the acceptance and use of information technologies [21,33]. The goal of TAM is to "provide an explanation of general determinants of computer acceptance”. Jiang et al. stated that it has become one of the most prominent theoretical models in this area.

Reasons to study TAM include improving user acceptance by changing the nature of a system involved, predicting how users will respond to changes, understanding why people resist using computers, and understanding determinants of technology adoption [1,11]. Figure 1 illustrates the original TAM. 


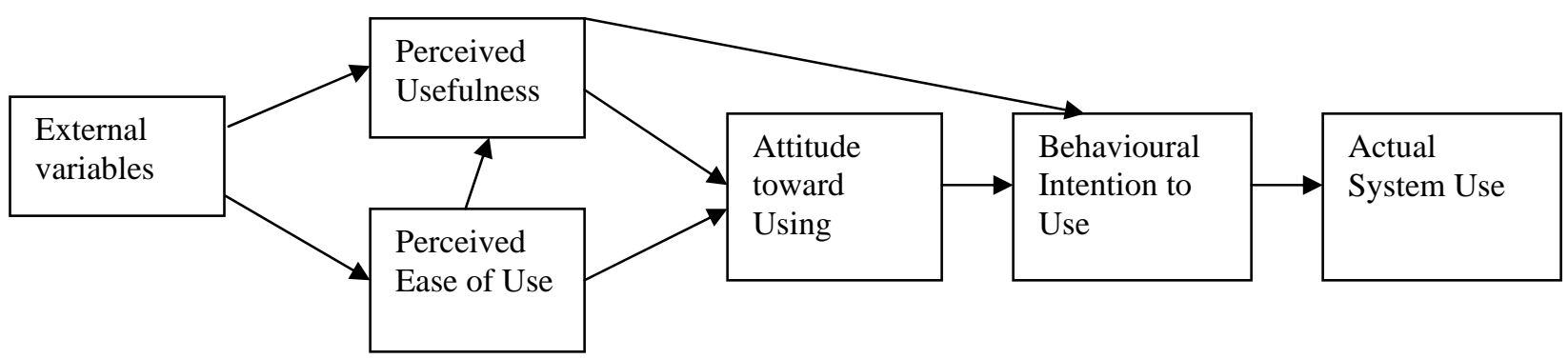

Figure 1: The Original Technology Acceptance Model

The construct Perceived Ease of Use was defined as "the degree to which a person believes that using a particular system would be free of effort.” Perceived Usefulness was described as "the degree to which a person believes that using a particular system would enhance his or her job performance." In addition, the original TAM contained the constructs Attitude toward Using, Behavioural Intention to Use and Actual Use.

\subsection{TAM studies focused on the Internet}

Many studies that have used TAM to predict Internet usage, focused on the Internet very generally (e.g.,[22,32]). These asked very broad questions in their surveys.

Focusing on the Internet has the drawback that the Internet covers a very wide variety of activities. A respondent could relate any one of these to their answers in the questionnaire. This means that the outcome may not be specific enough to study anything in detail. Churchill [9] recommended that focusing on a particular site would help to define a unit of analysis and therefore encourage a more accurate response with greater validity. 
A few studies have looked at one specific part of the Internet, focusing on using it for retail purposes (e.g.,[8, 28]) or work purposes. No studies focused on any other specific task (for example, using the Internet for information searching). Therefore, the focus of this paper is to apply TAM to a new application - use of the Internet for general information-searching purposes. This study investigated why users select search engines and what factors facilitate or impede their use.

\subsection{Intrinsic Motivation}

Intrinsic motives have been argued to play an important part in computer usage. People may use the Internet because they genuinely enjoy it. Intrinsic motivation can be defined, per Teo et al as: "the performance of an activity for no apparent reinforcement other than the process of performing the activity per se.” . They also defined extrinsic motivation as, "the performance of an activity because it is perceived to be instrumental in achieving valued outcomes that are distinct from the activity itself.”

One variable that could affect user acceptance is an intrinsic motivator, Flow, which can be described as a process of “optimal experience” or the most enjoyable experience possible [10]. Hoffman and Novak [18] suggested that a user will become engaged in a website if they experience the effects of Flow. If not, they will experience anxiety and boredom.

Moon and Kim extended TAM by including an intrinsic motivation factor, Perceived Playfulness, based on the concept of Flow. Chen et al. stated that playfulness is an important factor to motivate users to utilize a system. Moon and Kim defined Perceived 
Playfulness as: "The extent to which the individual Perceives that his or her attention is focused on the interaction with the World Wide Web; Is curious during the interaction; and Finds the interaction intrinsically enjoyable or interesting.”

In their study, they found that Perceived Playfulness had a significant positive relationship with Attitude toward Using. They concluded that it is important for developers to include intrinsic and extrinsic motivational factors in user interface design, thus helping to improve usability.

While Moon and Kim's study found evidence supporting an additional construct, Perceived Playfulness, as part of the TAM, no attempt was made to further identify possible variables that may have caused Perceived Playfulness to be experienced.

\subsection{Antecedents identified from existing literature}

Identification of antecedent conditions of Perceived Playfulness is important in order to understand what factors determine this construct and therefore Actual Use of a system. This section identifes several antecedents from existing studies in the Flow and Engagement literature. Agarwal and Karahanna [2] noted that the theories have considerable overlap; they all represent intrinsic motivation. They define flow and engagement as:

Flow: Includes, "intense concentration, a sense of being in control, a loss of self-consciousness and a transformation of time.” 
Engagement: Has the dimensions of, "Intrinsic interest, curiosity and attention focus.”

Within these constructs, the antecedents will be further divided up into two categories: cognitive antecedents relating to internal feelings and antecedents relating to website characteristics.

Antecedents of a Cognitive Nature: Several researchers have explored antecedents of Flow (eg., $[16,17]$,$) . Ghani et al. defined Flow as including Concentration and Enjoyment. They$ found that the constructs Individual Skills, Perceived Control and Perceived Challenge were antecedents of Flow when a task was computer-mediated. Similarly, Ghani and Deschpande found that Perceived Control and Challenge were significantly related to Flow. Hoffman and Novak identified four antecedents of Flow as: Skills and Challenges, Focused attention, Telepresence, and Interactivity.

Webster and Ho [36] explored antecedents of the construct Engagement and defined it as including Attention Focus, Curiosity, and Intrinsic Interest. They also found that a user required Challenge and Control to experience Engagement.

In addition, the studies in Table 1 also focused on antecedents of Flow, Perceived Playfulness and Cognitive Absorption: 


\begin{tabular}{|l|l|l|l|}
\hline Authors & $\begin{array}{l}\text { Construct } \\
\text { Label }\end{array}$ & Dimensions & Antecedents \\
\hline $\begin{array}{l}\text { Agarwal and Karahanna } \\
{[2]}\end{array}$ & $\begin{array}{l}\text { Cognitive } \\
\text { Absorption }\end{array}$ & $\begin{array}{l}\text { Temporal dissociation } \\
\text { Focused immersion } \\
\text { (Concentration \& Attention focus) } \\
\text { Heightened enjoyment } \\
\text { (Enjoyment \& Intrinsic Interest) } \\
\text { Control } \\
\text { Curiosity }\end{array}$ & $\begin{array}{l}\text { Personal Innovativeness } \\
\text { (Trait reflecting the willingness to try out } \\
\text { any new technology) } \\
\text { Playfulness } \\
\text { (Degree of cognitive spontaneity in } \\
\text { microcomputer interactions) }\end{array}$ \\
\hline Koufaris [20] & Flow & $\begin{array}{l}\text { Perceived control } \\
\text { Shopping enjoyment } \\
\text { Concentration }\end{array}$ & $\begin{array}{l}\text { Product involvement (e.g. how interested } \\
\text { user is in books and how important books } \\
\text { are to user) } \\
\text { Web skills (computer self-efficacy) } \\
\text { Challenges }\end{array}$ \\
\hline
\end{tabular}

Table 1: Studies focused on Cognitive Antecedents of Flow and other related constructs 
Antecedents relating to Website Characteristics: Website characteristics may also play a part in determining whether the user has a positive experience with the information searching website. Webster and Martocchio [37] found several significant antecedents of Flow relating to website characteristics: Flexibility and Modifiability, Experimentation, Perceived Communication Effectiveness, and Perceived Quality of Communication.

Webster and Ho found that user Engagement could be encouraged by Feedback and Variety of the system used. Webster and Hackley [35] also examined Engagement and found that Technology Characteristics (for example reliability and quality of the technology) affected Engagement.

In addition, the studies in Table 2 focused on antecedents of Flow, Perceived Playfulness, and Cognitive Absorption: 


\begin{tabular}{|l|l|l|l|}
\hline Authors & $\begin{array}{l}\text { Construct } \\
\text { Label }\end{array}$ & Dimensions & Antecedents \\
\hline Chan [7] & Flow & $\begin{array}{l}\text { Involvement and Immersion } \\
\text { Concentration and Attention } \\
\text { Intrinsic enjoyment } \\
\text { Time distortion } \\
\text { Continuous interactions }\end{array}$ & $\begin{array}{l}\text { Ease } \\
\text { Navigation } \\
\text { Speed } \\
\text { Content }\end{array}$ \\
\hline Koufaris [20] & Flow & $\begin{array}{l}\text { Perceived control } \\
\text { Shopping enjoyment } \\
\text { Concentration }\end{array}$ & Value-added search mechanisms \\
\hline Moon and Kim [25] & Perceived & $\begin{array}{l}\text { Focused Attention } \\
\text { Curiosity } \\
\text { Enjoyment }\end{array}$ & Perceived Ease of Use \\
\hline
\end{tabular}

Table 2: Studies focused on Website Characteristic Antecedents of Flow and other related constructs 


\subsection{Possible Antecedents of Perceived Playfulness}

In summary, the following have been identified as possible antecedents of Perceived Playfulness.

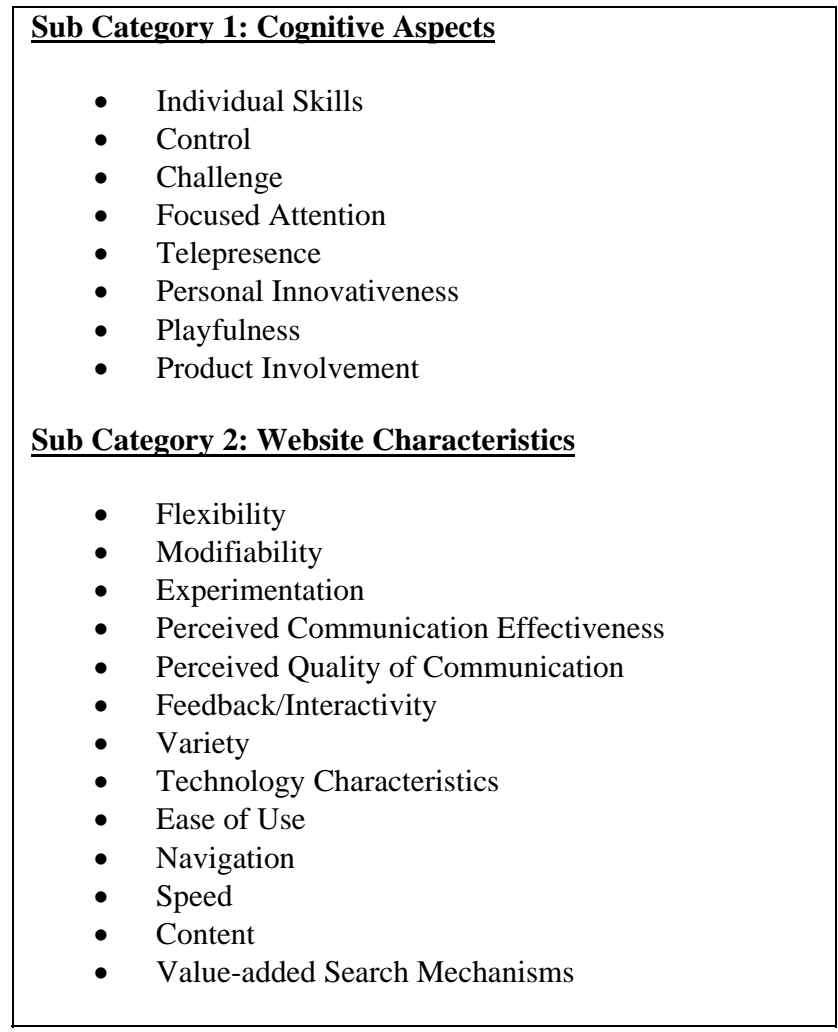

Figure 2: Possible Antecedents of Perceived Playfulness

Many antecedents have been identified as being in a causal relationship with similar constructs to Perceived Playfulness. It is important to understand what factors might encourage Playfulness. However, an observation is that these antecedents have been tested in different contexts. No studies have been found examining antecedents of Perceived Playfulness in the TAM context, where Perceived Playfulness is used as a predictor of Attitude toward Using. It is hard to tell whether the antecedents found to be viable in one context, might be viable in another. Pijpers et al. stated that although a number of studies 
had identified numerous antecedent conditions, no consistent groups of variables had been found.

\section{Development of the Research Problem}

From the literature review, several limitations were identified. It was noted that there was a lack of focus on the use of TAM in the context of the Internet for information searching. Also, the original TAM did not include intrinsic motivation factors, which may be an important part of user acceptance.

The research problem explored in this paper therefore was:

\section{What are the antecedents of Perceived Playfulness when using the Internet for general information-searching purposes?}

\section{Research Methodology}

\subsection{Theoretical Framework}

The theoretical framework adapted the original TAM which was extended to include the antecedents of Perceived Playfulness. 


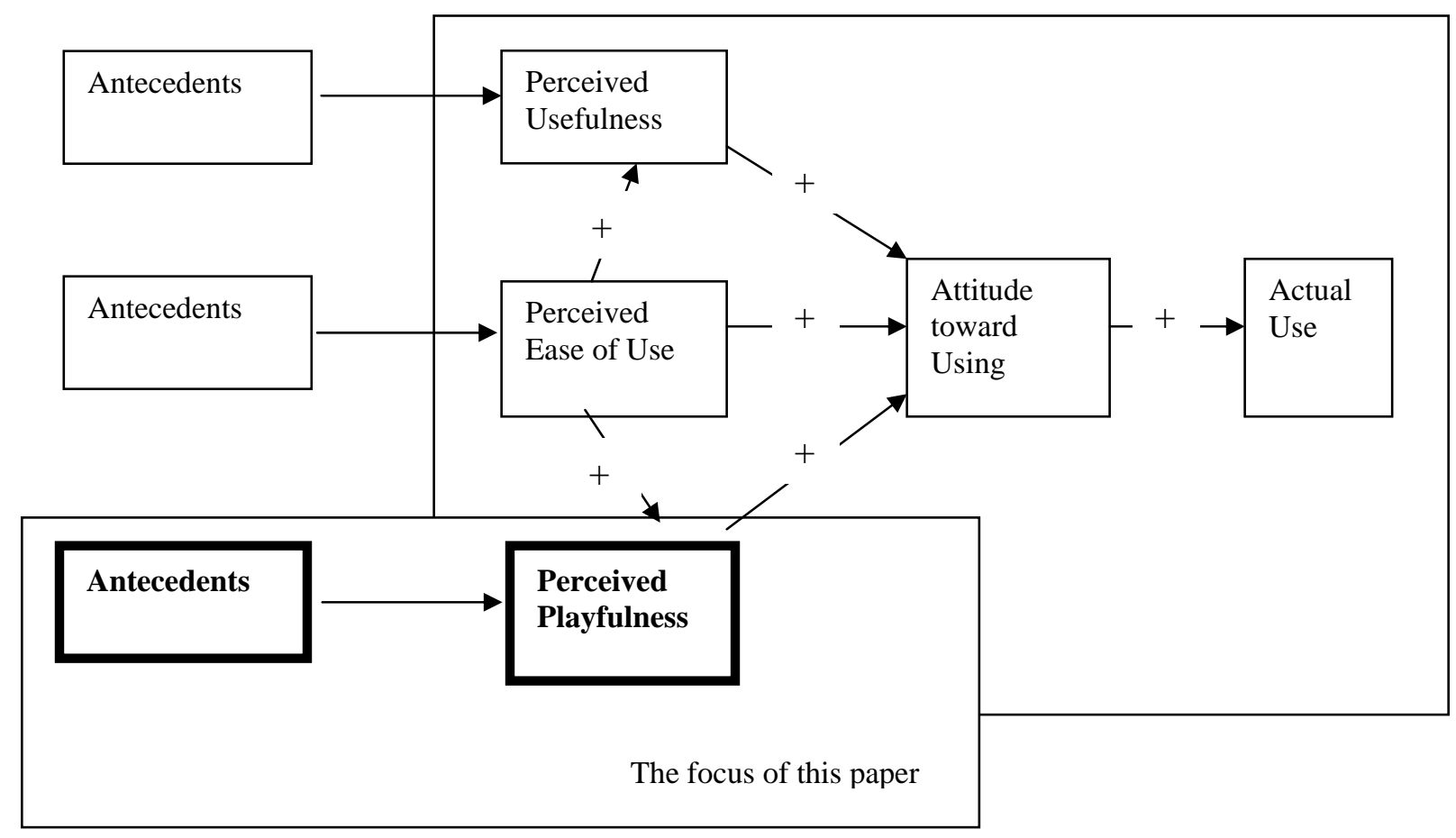

Figure 3: The Theoretical Model

\subsection{Sampling}

Our data sample consisted of responses of students attending Information Systems classes. The sample included students attending five undergraduate lectures and one postgraduate lecture. The selection of this sample was that of convenience, due to our limited time and budget. Students were chosen because they were likely to be computer literate and would have had experience in using the Internet on a regular basis.

\subsection{Research Design}

A questionnaire was used to collect the data. A participant information sheet was also given to each respondent; this introduced the researcher and the purpose of the study. The questionnaires were handed out to students as they entered their lecture rooms and were 
collected immediately after they were completed. Thus the sample was not geographically-dispersed.

The questionnaire focused on the task of Information Searching on the Internet. The respondents were asked to state a specific site they had used recently. This was to ensure that the respondent answered the questions with a specific site in mind, enabling greater accuracy in answers given.

As part of the overall questionnaire, an open-ended question was also included; this was intended to aid in exploring antecedents of Perceived Playfulness. This allowed the respondent to specify antecedents in a non-structured environment. The question asked the respondents to specify what factors they felt contributed to them engaging in a positive and/or negative experience when using the site that they had specified. The respondents were encouraged to think of "experience" in terms of how focused they had felt when interacting with the site, how inquiring or curious they were about the interaction, and how enjoyable or interesting they found the site.

The questionnaire was pilot tested in order to assess whether independent respondents could understand items in the questionnaire. Questionnaires were therefore administered to two lecturers and eight students. These respondents resembled the target sample to be surveyed. The pre-test instructed respondents to fill out the questionnaire and report on any feedback. 


\subsection{Data Analysis}

Content analysis was used to identify antecedents of Perceived Playfulness from the questionnaires. Neuendorf [26] defined content analysis as, “a summarizing, quantitative analysis of messages that relies on the scientific method... and is not limited to the types of variables that may be measured or the context in which the messages are created or presented.” Cavana et al stated that the goal of content analysis is to identify independent themes from raw data.

Figure 4 depicts the flowchart of the process for content analysis adapted from Neuendorf. This process was employed in carrying out content analysis:

\section{Conceptualisations:}

- Decide on variables, which will be used in the study

- Ensure the variables can be defined conceptually

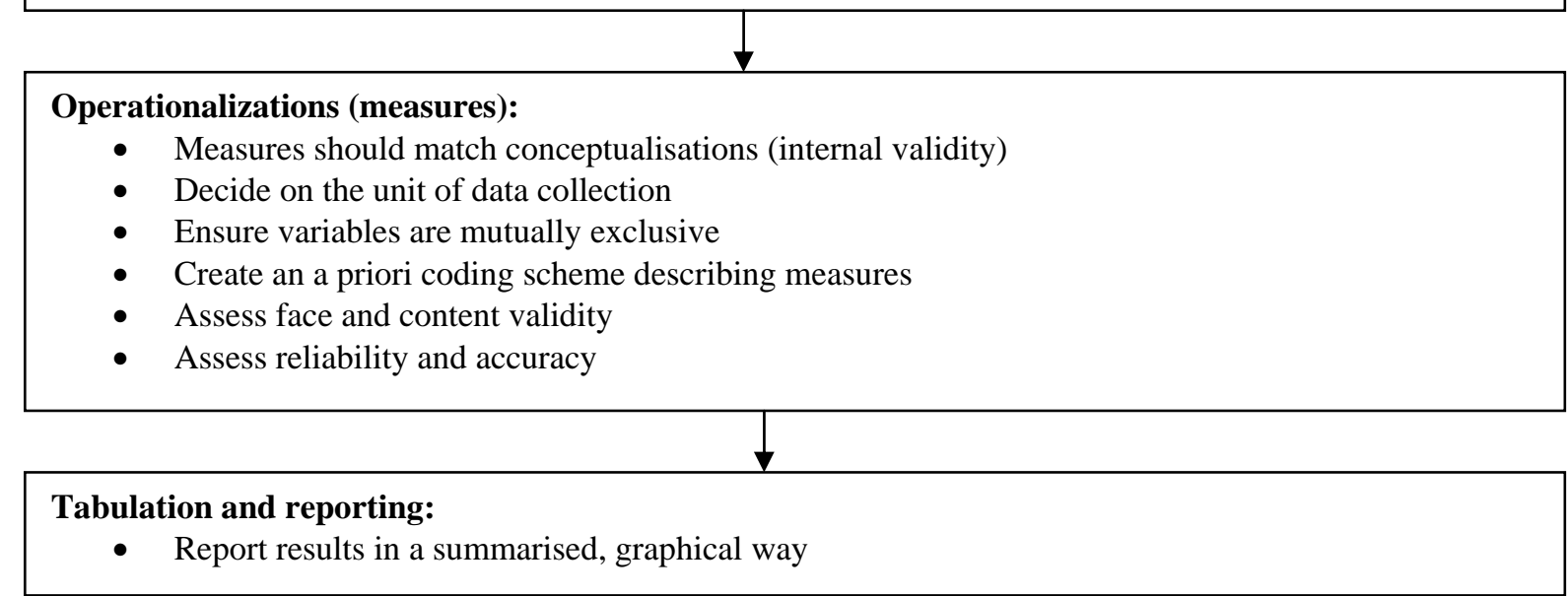

Figure 4: Flow Chart of Content Analysis Process 
More details can be found in Appendix A. An a priori coding scheme was generated from the possible antecedents of Perceived Playfulness identified previously. To ensure that variables were mutually exclusive, each construct was clearly defined.

\section{Results}

\subsection{Respondent Background}

In total, 292 questionnaires were handed out and 185 were returned; of these, 154 were deemed to be complete for statistical analysis purposes. This is a response rate of $63 \%$. A response rate of over $51 \%$ is considered adequate in the social sciences research area.

Table 3 gives a summary of the backgrounds of the 154 respondents:

\begin{tabular}{|l|l|l|}
\hline Variable & $\begin{array}{l}\text { Frequency } \\
(\mathbf{n}=\mathbf{1 5 4})\end{array}$ & Percentage \\
\hline Age & & \\
Under 20 & 32 & $21 \%$ \\
$\mathbf{2 0 - 2 9}$ & 113 & $\mathbf{7 3 \%}$ \\
Over 30 & 9 & $6 \%$ \\
& & \\
\hline Gender & & \\
Male & 105 & $\mathbf{6 8 \%}$ \\
Female & 49 & $32 \%$ \\
\hline Highest Education & & \\
High School & 91 & $\mathbf{5 9 \%}$ \\
Undergraduate & 52 & $34 \%$ \\
Postgraduate & 11 & $7 \%$ \\
\hline Ethnicity & & \\
Asian & 80 & $\mathbf{5 2 \%}$ \\
European & 38 & $\mathbf{2 5 \%}$ \\
Indian & 10 & $6 \%$ \\
Other & 26 & $17 \%$ \\
\hline
\end{tabular}

Table 3: Respondent Demographic Information 
$73 \%$ of the respondents were between the ages of 20 and 29 years old. This was to be expected, as students were sampled. The data gathered from this sample was representative of Information Systems students, but was not necessarily generalizable to the wider population from which it was drawn.

Respondents had been asked to specify and evaluate their experience on a website they had recently used: 52\% answered the questionnaire based on the site www.google.com, while $23 \%$ used www.yahoo.com. The rest used a wide range of other websites.

\subsection{Data Analysis of Antecedents}

Respondent answers on why they did not have a positive experience in using a particular site were reversed by assuming that the opposite of what they said would be true if they had had a positive experience. Figure 5 illustrates the antecedents found for Perceived Playfulness: 


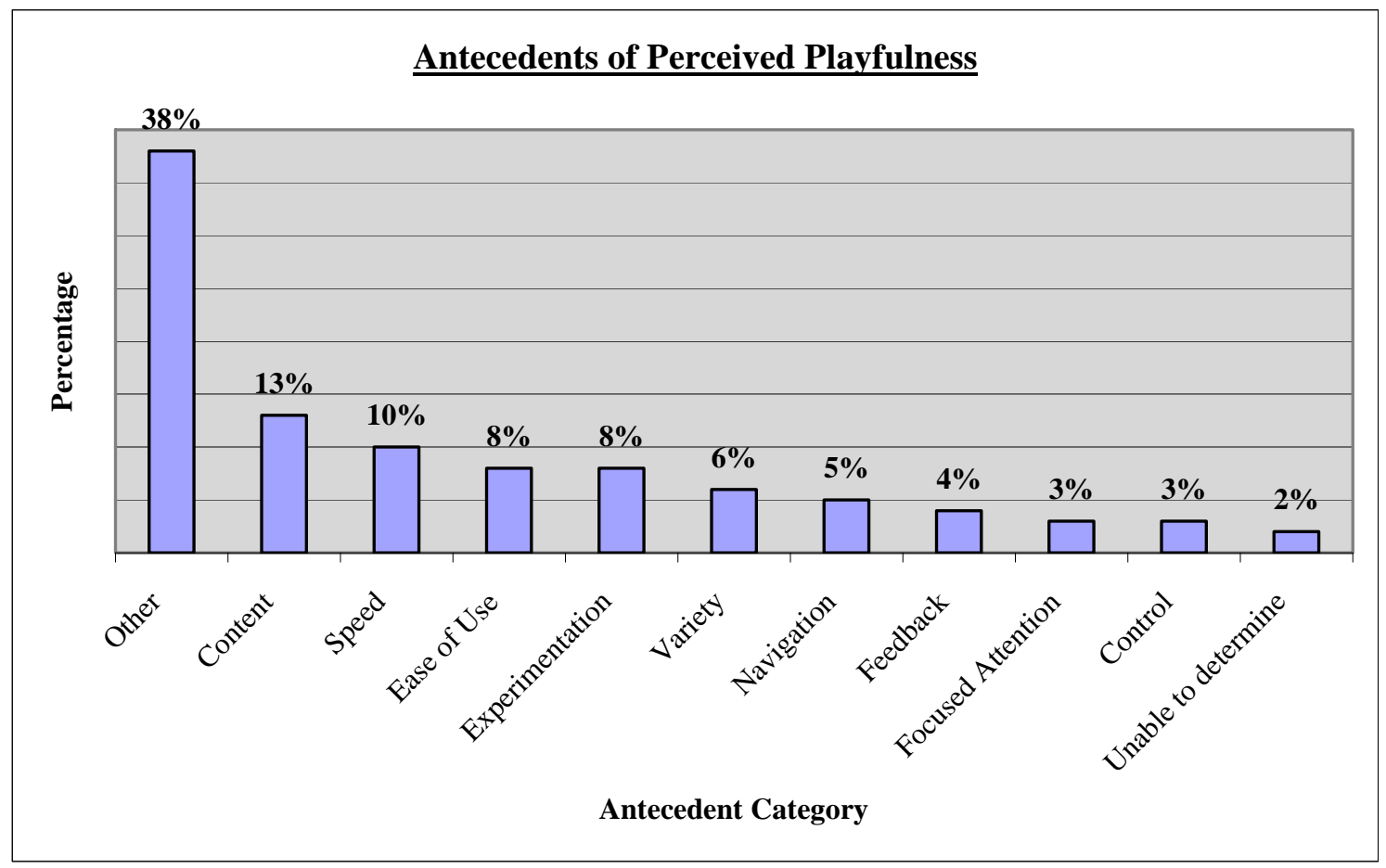

Figure 5: Graph showing Antecedents of Perceived Playfulness

Interestingly, 38\% of respondents were coded under the "other” category, indicating that their answers could not be coded using the a priori scheme. These answers were then separated into two other categories “perceived usefulness” (29\%) and “experientialdirected task” (9\%). An example of a response coded under "perceived usefulness” was, "usefulness of the site in terms of information obtained."

An example of a response coded as "experiential-directed task” was, "it’s a search engine...I just want information,” indicating that the respondent would require an experiential-directed task to experience Perceived Playfulness. Bloch et al. [5] stated that experiential behaviour occurs where "activities are not guided by goals or outcomes, but by the process itself.” Therefore, experiential behaviour is more suitable for recreational 
activities where the user wants to explore leisurely. Goal-directed behaviour (the opposite of experiential behaviour) is more suited for activities where the user knows what he or she wants and can find it straight away.

Table 4 shows the percentage of respondents who answered under each category and examples of each: 


\begin{tabular}{|c|c|c|c|}
\hline Antecedent Category & $\begin{array}{l}\text { Main Sub } \\
\text { Category }\end{array}$ & Percentage & Example \\
\hline Content & $\begin{array}{l}\text { Website } \\
\text { Characteristic }\end{array}$ & $13 \%$ & $\begin{array}{l}\text { "The page was entirely dedicated to the search } \\
\text { and not for their sponsors to put banners on which } \\
\text { left more space for search results making them } \\
\text { easier to read" } \\
\text { "Interesting tips and information in the site e.g. } \\
\text { facts and figures" } \\
\text { "...content contributed to the experience" }\end{array}$ \\
\hline Speed & $\begin{array}{l}\text { Website } \\
\text { Characteristic }\end{array}$ & $10 \%$ & $\begin{array}{l}\text { "The ability to acquire information required } \\
\text { quickly" } \\
\text { "Fast response" } \\
\text { "Fast loading" } \\
\text { “...finding the info I was interested in, quickly..” } \\
\text { "Information generated quickly" }\end{array}$ \\
\hline Ease of Use & $\begin{array}{l}\text { Website } \\
\text { Characteristic }\end{array}$ & $8 \%$ & $\begin{array}{l}\text { “...Google allowed me to complete it easily” } \\
\text { "Simple search function, ease of use..." } \\
\text { "Ease of use..." } \\
\text { "Ease of use, good results" } \\
\text { "Ease of finding things" }\end{array}$ \\
\hline Experimentation & $\begin{array}{l}\text { Website } \\
\text { Characteristic }\end{array}$ & $8 \%$ & $\begin{array}{l}\text { "...led to new things I did not think about" } \\
\text { "Provided sites I could use for other things" }\end{array}$ \\
\hline Variety & $\begin{array}{l}\text { Website } \\
\text { Characteristic }\end{array}$ & $6 \%$ & $\begin{array}{l}\text { "The information I get...varies" } \\
\text { "Innovative features - e.g. picture search" } \\
\text { "Information gained, pictures" } \\
\text { "Could search with pictures, lots of links" }\end{array}$ \\
\hline Navigation & $\begin{array}{l}\text { Website } \\
\text { Characteristic }\end{array}$ & $5 \%$ & $\begin{array}{l}\text { "No broken links" } \\
\text { “....well laid out, easy to change focus..." } \\
\text { “...links ... to other archival information pages" }\end{array}$ \\
\hline Feedback & $\begin{array}{l}\text { Website } \\
\text { Characteristic }\end{array}$ & $4 \%$ & $\begin{array}{l}\text { "The site is interactive. You interact with tens of } \\
\text { thousands of other users of your same age" } \\
\text { "....kept me interacting with the site ...." }\end{array}$ \\
\hline Focused Attention & Cognitive & $3 \%$ & $\begin{array}{l}\text { "Was very focused, very curious and quite } \\
\text { interesting" } \\
\text { "The site does not have too many ads and topics } \\
\text { so I do not get easily distracted" }\end{array}$ \\
\hline Control & Cognitive & $3 \%$ & "I could choose how results were displayed" \\
\hline
\end{tabular}

Table 4: Examples of Antecedent Categories found in Data analysed 


\section{Discussion}

\subsection{Findings}

Some caution should be taken in interpreting these results, due to the nature of the sample (by convenience) and its somewhat limited generalizability.

The overall findings were that several antecedents of Perceived Playfulness were found. Many were identified and validated from existing literature, originally taken from Flow and Engagement. The outcome has been that website characteristics play a dominant role in allowing users to experience Perceived Playfulness. The antecedents which related to website characteristics were Content, Speed, Ease of Use, Experimentation, Variety, Navigation, and Feedback.

The user may require good content, a fast response, and ease of use in order to experience Perceived Playfulness. Users may also require a sense of curiosity or experimentation, variety within the site, easy navigation, and feedback from the website.

Also of importance were the cognitive elements associated with user experiences. These were Focused Attention and Control. Absorption in the task and feeling in control may help the user to experience Perceived Playfulness.

Two emergent antecedents of Perceived Playfulness were identified: the need for Perceived Usefulness and Experiential-Directed Tasks. 
With regards to the wider literature in support of Perceived Usefulness as an antecedent of Perceived Playfulness, Davis et al. [14] found that there was a positive relationship between Perceived Usefulness and Enjoyment (a similar construct to Perceived Playfulness). They stated that increasing the enjoyment of a system would also increase the perceived usefulness of a system. The antecedent Perceived Usefulness can be categorised under the sub category "Website Characteristics" as usefulness is a characteristic of a site.

In support of Experiential-Directed Task as an antecedent, Chan [7] stated that Flow is more apparent in experiential activities than in goal-directed activities, demonstrating that an Experientially-Directed Task may be needed in order to experience Perceived Playfulness. Furthermore, experiential behaviour may be particularly evident during activities such as browsing and exploring websites. Conversely, Ghani and Deschpande found that Flow was an antecedent of exploratory use (use of computers for exploration or experimentation. The antecedent Experiential-directed Task does not fall under any of the

proposed sub categories (Cognitive Aspects or Website Characteristics). Wolfinbarger and Gilly [38] stated that consumer motivation is largely either goal-directed (for a purpose) or experiential (for fun and exploration). Therefore, a new category, Motivation for Searching, is proposed.

\subsection{Proposed Model}

From our results we have proposed a model of possible antecedents of Perceived Playfulness (see Figure 6). This separates the antecedents into three broad categories: Cognitive Aspects, Website Characteristics, and Motivation for Searching. 


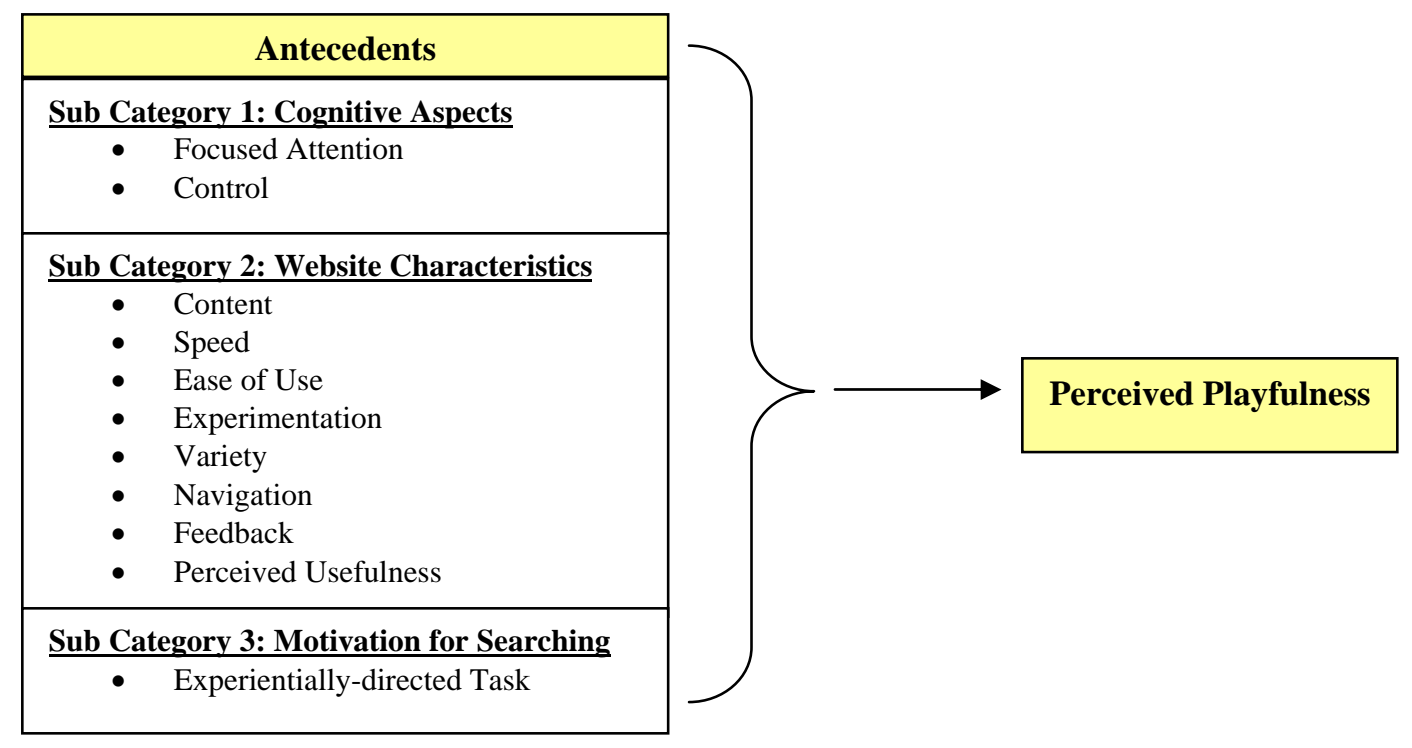

Figure 6: Proposed Model for Antecedents of Perceived Playfulness 


\subsection{Limitations of the Research}

There were several limitations in our research:

(1) Sampling Design: The sample was taken on a convenience basis. It allowed information to be collected quickly and effectively. However this method is probably the least reliable of all sampling methods because results cannot be generalised. Therefore, a limitation of the research was that the sample was not generalizable to the population.

(2) Results: When content analysis was carried out, only one category was coded for each whole text given by a respondent. If two categories were apparent within a respondent's answer this was coded under the category that appeared to be most appropriate. Therefore, some categories may have been under-represented. Also, several responses had to be reversed to create a positive answer. An assumption was then made that the respondent would have given this answer had he or she encountered a positive experience.

\section{Conclusion}

Several antecedent categories of Perceived Playfulness were found from our data as analysed: most matched antecedents already found in the Flow context. Of particular interest were Perceived Usefulness and Experiential-directed Task.

Results showed that identified antecedents could be separated into three broad categories:

Cognitive Aspects, Website Characteristics, and Motivation for Searching. 
Several implications for business practice can be identified. Our findings have provided several antecedent categories, which could lead to consideration of how the construct Perceived Playfulness can be obtained in practice. However, these implications must be interpreted with caution, keeping in mind the limitations.

We found that Content, Speed, Ease of Use, Experimentation, Variety, Navigation, Feedback, Perceived Usefulness (Website Characteristics), Focused Attention, Control (Cognitive Aspects), and Experiential-Directed Type of Task (Motivation for Searching) influenced perceptions regarding playfulness of the site. Designers should take these factors into account.

Overall, this study contributed to existing research by exploring antecedents of Perceived Playfulness and proposing several new antecedent categories of the construct. The findings should enable designers of information searching websites to create sites that encourage maximum user acceptance through the understanding of TAM and its antecedents, in particular, the antecedents of Perceived Playfulness. This will therefore promote information searching on the Internet as a positive experience for users. 


\section{Appendix A}

This appendix details the Content Analysis approach taken in this study, based on a typical process identified by Neuendorf.

\section{Conceptualisations}

The research problem asked concerned identification of the antecedents of Perceived Playfulness for information searching sites on the Internet. Variables used in the analysis were antecedents of Perceived Playfulness.

\section{Operationalizations (measures)}

The unit of data collection used was “whole text”. Therefore, each respondent's entire answer to a single question was coded under one antecedent category only. Weber [34] stated that it is hard to achieve high reliability where whole text is coded. However, all respondent answers were brief (1-3 sentences) therefore it was thought appropriate to code the entire text. Where more than one category was identifiable within the answer, the category most appropriate was chosen. This was a limitation of the study, as categories could be under-represented if more than one category were evident within a single text.

Antecedent categories (which matched the conceptual variables defined earlier) were assessed for mutual exclusivity, and repeated or similar categories were combined together. An a priori coding scheme was developed from these categories. Neuendorf stated that all 
decisions about variables, their definitions and coding rules should be established before data is analysed. Designing the coding scheme meant excluding some antecedent categories identified in the literature review. This was due to their assumed irrelevance to this study of using the Internet for information searching purposes.

Validity: Looking at the coding scheme categories and ensuring they measured what they were intended to measure ensured face validity. Furthermore, the categories were formed from existing literature therefore ensuring the categories were valid.

Reliability and Accuracy: Neuendorf defined reliability as, "the extent to which a measuring procedure yields the same results on repeated trials... a measure is not valuable if it can be conducted only once...” Conducting a second test of a coding sample of 30 responses (10 for each construct) to assess whether the same results were achieved ensured reliability of the analysis. Creating a detailed coding scheme and applying the same rules to every text coded ensured that accuracy was achieved.

\section{Tabulation and reporting}

Findings from the content analysis attempted to address the research problem - what were the antecedents of Perceived Playfulness for information searching sites on the Internet. Data gathered was summarised and reported by using bar graphs depicting antecedents found for each of the three constructs. Text coded as "other” was assessed as to whether new categories, not included in the a priori coding scheme could be formed 


\section{A Priori Coding Scheme}

The following table specifies the a priori coding scheme of final antecedent categories for Perceived Playfulness that was used for content analytical coding: 


\begin{tabular}{|c|c|c|}
\hline $\begin{array}{l}\text { Antecedent } \\
\text { Name }\end{array}$ & Antecedent Definition & $\begin{array}{l}\text { Authors who found the antecedent } \\
\text { to be significant in determining } \\
\text { Flow/Engagement/Cognitive } \\
\text { Absorption }\end{array}$ \\
\hline Control & $\begin{array}{l}\text { Extent to which user feels in charge of } \\
\text { the interaction }\end{array}$ & $\begin{array}{l}\text { Ghani and Deshpande [14], Ghani et } \\
\text { al. [15], Webster \& Ho [32], Chan } \\
\text { [7], Novak et al. [27] }\end{array}$ \\
\hline Challenge & $\begin{array}{l}\text { Extent to which perceived positive } \\
\text { challenges (e.g. difficulty of task) } \\
\text { presented by an activity are matched to } \\
\text { perceived skills of the user }\end{array}$ & $\begin{array}{l}\text { Ghani and Deshpande [14], Ghani et } \\
\text { al. [15], Hoffman and Novak [16], } \\
\text { Webster and Ho [32], Novak et al. } \\
\text { [27], Koufaris [20] }\end{array}$ \\
\hline Ease of use & Ease by which site can be used & Chan [7], Moon and Kim [25] \\
\hline Experimentation & $\begin{array}{l}\text { Extent to which user can experiment } \\
\text { with the given technology }\end{array}$ & Webster and Martocchio [33] \\
\hline Focused attention & $\begin{array}{l}\text { Attention is completely absorbed by } \\
\text { the activity }\end{array}$ & Hoffman and Novak [16] \\
\hline Telepresence & $\begin{array}{l}\text { Extent to which a user feels present in } \\
\text { a virtual, rather than in a physical } \\
\text { environment }\end{array}$ & $\begin{array}{l}\text { Hoffman and Novak [16], Novak et } \\
\text { al. [24] }\end{array}$ \\
\hline Feedback & $\begin{array}{l}\text { Ability to interact with the site/gain } \\
\text { feedback from the site }\end{array}$ & $\begin{array}{l}\text { Hoffman and Novak [16], Webster } \\
\text { and Ho [32] }\end{array}$ \\
\hline Variety & Ability to gain variety from the site & Webster and Ho [32] \\
\hline $\begin{array}{l}\text { Personal } \\
\text { Innovativeness }\end{array}$ & Willingness to try out something new & Agarwal and Karahanna [2] \\
\hline Navigation & $\begin{array}{l}\text { Extent to which user can navigate } \\
\text { through the site }\end{array}$ & Chan [7] \\
\hline Speed & Speed of use of the site & Chan [7] \\
\hline Content & Content/layout within the site & Chan [7] \\
\hline Time distortion & Transformation of time & Novak et al. [27] \\
\hline $\begin{array}{l}\text { Computer self- } \\
\text { efficacy/ skills }\end{array}$ & $\begin{array}{l}\text { Individual's belief about his/her } \\
\text { capabilities to use computers, } \\
\text { judgements of how well one can } \\
\text { execute courses of action required to } \\
\text { deal with prospective situations }\end{array}$ & $\begin{array}{l}\text { Koufaris [20], Ghani et al. [15], } \\
\text { Hoffman and Novak [16], Novak et } \\
\text { al. [27] }\end{array}$ \\
\hline $\begin{array}{l}\text { Value-added } \\
\text { search } \\
\text { mechanisms }\end{array}$ & $\begin{array}{l}\text { Extent to which search mechanisms aid } \\
\text { in allowing the user to find what they } \\
\text { need, learn more about it etc. }\end{array}$ & Koufaris [20] \\
\hline Other & $\begin{array}{l}\text { Text does not fit in with any other } \\
\text { category }\end{array}$ & \\
\hline $\begin{array}{l}\text { Unable } \\
\text { determine }\end{array}$ & $\begin{array}{l}\text { Unable to determine } \\
\text { category }\end{array}$ & \\
\hline
\end{tabular}




\section{References}

[1] D. Adams, R. Nelson and P. Tood "Perceived Usefulness, Ease of Use and Usage of Information," MIS Quarterly (16:2), 1992, pp. 227-247.

[2] R. Agarwal and E. Karahanna "Time flies when you're having fun: Cognitive Absorption and Beliefs about Information Technology Usage," MIS Quarterly (24:4), 2000, pp. 665-694.

[3] R. Agarwal and V. Venkatesh "Asessing a Firm's Web Presence: A Heuristic Evaluation Procedure for Measurement of Usability," Information Systems Research (13:2), 2002, pp. 168-186.

[4] R. Benbunan-Fich "Using protocol analysis to evaluate the usability of a commercial web site," Information and Management (39), 2001, pp. 151-163.

[5] P. Bloch, D. Sherrell and N. Ridgway "Consumer Search: An Extended Framework," Journal of Consumer Research (13), 1986, pp. 119-126.

[6] R. Cavana, B. Delahaye and U. Sekaran Applied Business Research: Qualitative and Quantitative Methods, John Wiley \& Sons Australia, Ltd, 2001.

[7] C.Y.N. Chan "An empirical investigation of interactivity and consumer online experience in hypermedia computer-mediated environments," University of Auckland, 2001.

[8] L.-d. Chen, M. Gillenson and D. Sherrell "Enticing online consumers: an extended technology acceptance perspective," Information and Management (39), 2002, pp. 705719.

[9] G.A. Churchill "A paradigm for developing better measures of marketing constructs," Journal of Marketing Research (16), 1979, pp. 64-73.

[10] M. Csikszentmihalyi Flow - The Psychology of Optimal Experience, Harper \& Row, New York, 1990.

[11] F. Davis "Perceived Usefulness, Perceived Ease of Use, and User acceptance of Information Technology," MIS Quarterly (13), 1989, pp. 318-339.

[12] F. Davis "User acceptance of information technology: system characteristics, user perceptions and behavioural impacts," International Journal of Man-Machine Studies (38:3), 1993, pp. 475-487.

[13] F. Davis, R. Bagozzi and P. Warshaw "User acceptance of computer technology: a comparison of two theoretical models," Management Science (35:8), 1989, pp. 982-1003. 
[14] F. Davis, R. Bagozzi and P. Warshaw "Extrinsic and intrinsic motivation to use computers in the workplace," Journal of Applied Social Psychology (22:14), 1992, pp. 1111-1132.

[15] V. Earle Searching the Web: A smart guide to on-line skills, The Open Polytechnic of New Zealand, 1999.

[16] J. Ghani and S. Deshpande "Task Characteristics and the Experience of Optimal Flow in Human-Computer Interaction," The Journal of Psychology (128:4), 1994, pp. 381-391.

[17] J. Ghani, R. Supnick and P. Rooney "The Experience of Flow in Computer-Mediated and in Face-to-Face groups," Proceedings of the Twelfth International Conference on Information Systems, New York, 1991.

[18] D. Hoffman and T. Novak "Marketing in hypermedia computer-mediated environments: Conceptual foundations," Journal of Marketing (60:3), 1996, pp. 50-68.

[19] J. Jiang, M. Hsu, G. Klein and B. Lin "Human Systems Management," 19), 2000, pp. 265-276.

[20] M. Koufaris "Applying the Technology Accpetance Model and Flow theory to Online Consumer Behaviour," Information Systems Research (13:2), 2002, pp. 205-223.

[21] A. Lederer, D. Maupin, M. Sena and Y. Zhuang "The technology acceptance model and the World Wide Web," Decision support systems (29), 2000, pp. 269-282.

[22] S. Liaw "Understanding user perceptions of World-wide web environments," Journal of Computer Assisted Learning (18), 2002, pp. 137-148.

[23] C. Liu and K.P. Arnett "Exploring the factors associated with Web site success in the context of electronic commerce," Information \& Management (38:1), 2000, pp. 23-33.

[24] T. Malone "Toward a theory of intrinsically motivating instruction," Cognitive Science (4), 1981, pp. 333-369.

[25] J.-W. Moon and Y.-G. Kim "Extending the TAM for the World-Wide-Web context," Information and Management (38), 2001, pp. 217-230.

[26] K. Neuendorf The Content Analysis Guidebook, Sage Publications, Inc, California, 2002.

[27] T. Novak, D. Hoffman and Y.-F. Yung "Measuring the customer experience in online environments: A structural modeling approach," Marketing Science (19:1), 2000. 
[28] A. O'Cass and T. Fenech "Web retailing adoption: Exploring the nature of Internet users web retailing behaviour," Journal of Retailing and Consumer Services (10:2), 2003, pp. 81-94.

[29] G. Pijpers, T. Bemelmans, F. Heemstra and K. van Montfort "Senior executives' use of information technology," Information and Software Technology (43), 2001, pp. 959-971.

[30] A. Pinsonneault and K. Kraemer "Survey research methodology in management information systems: An assessment," Journal of Management Information Systems (10:2), 1993, pp. 75-105.

[31] C. Ranganathan and S. Ganapathy "Key dimensions of business-to-consumer web sites," Information \& Management (39:6), 2002, pp. 457-465.

[32] T. Teo, V. Lim and R. Lai "Intrinsic and Extrinsic motivation in Internet Usage," Omega (27), 1999, pp. 25-37.

[33] V. Venkatesh and F. Davis "A model of the antecedents of perceived ease of use: development and test," Decision Sciences (27:3), 1996, pp. 451-481.

[34] R. Weber Basic Content Analysis, Sage Publications, Inc, California, 1990.

[35] J. Webster and P. Hackley "Teaching Effectiveness in Technology-Mediated Distance Learning," Academy of Management Journal (40:6), 1997, pp. 1282-1309.

[36] J. Webster and H. Ho "Audience Engagement in Multi-Media Presentations," Data Base for the Advances in Information Systems (28:2), 1997, pp. 63-77.

[37] J. Webster and J. Martocchio "Turning Work into Play: Implications for Microcomputer Software Training," Journal of Management (19:1), 1993, pp. 127-146.

[38] M. Wolfinbarger and M. Gilly "Shopping Online for Freedom, Control and Fun," California Management Review (43:2), 2001, pp. 34-55. 